\title{
SOIL PHYSICAL PROPERTIES IN A LONG-TERM CONSERVATION SYSTEM FOR ONION
}

\author{
Belo Afonso Muetanene ${ }^{1}$, Álvaro Luiz Mafra ${ }^{2}$, Jackson Adriano Albuquerque ${ }^{2}$, Luiz Alexandre \\ Peternelli ${ }^{3}$, Claudinei Kurtz ${ }^{4}$ \\ ${ }^{1}$ UniLúrio - Rural Engineering Department, Faculty of Agronomic Sciences, Moçambique, Africa \\ ${ }^{2}$ Santa Catarina State University - Soil and Natural Resources Department, Santa Catarina State, Brazil \\ ${ }^{3}$ Federal University of Viçosa, Viçosa, Minas Gerais State, Brazil \\ ${ }^{4}$ Company of Agricultural Research and Rural Extension of Santa Catarina State, Ituporanga, Experimental Station, \\ Santa Catarina State, Brazil \\ E-mail: floriafonso@gmail.com, alvaro.mafra@udesc.br, jackson.irai@gmail.com, peternelli@ufv.br, \\ kurtz@epagri.sc.gov.br
}

\section{ABSTRACT}

The objective of this study was to evaluate soil physical properties under different cropping systems for onion. The study was conducted on an Inceptisol in Ituporanga, Santa Catarina state, Brazil. We evaluated eight cropping systems for onion: T1: maize-onion succession; T2: common vetch-maize/rye+fodder radish-onion-maize/rye+fodder radish-common bean; T3: rye-onionmaize/black oat-maize; T4: onion-velvet bean succession; T5: rye-onion-millet/black oat-onionmillet; T6: rye-onion-velvet bean succession; T7: onion-velvet bean+millet+sunflower succession. Treatments from T1 to T7 were conducted under no-tillage system (NTS) and T8: maize-onion succession under a conventional tillage system. We used the randomized complete block design, with five replications. Undisturbed soil samples were collected at the 0-5, 5-10 and 10-15 cm soil layers and we evaluated the following soil physical properties: geometric mean diameter of aggregates, total porosity, macroporosity, microporosity, bulk density and the ratio macroporosity/ total porosity. The data analysis was performed using univariate statistics, principal components analysis (PCA) and cluster analysis (CA). Based on the cropping systems characteristics, the CA divided them into three groups: group 1: T7; group 2: T1, T2, T3, T4, T5, T6; and group 3: T8. T8 showed evidence of soil physical quality deterioration at the soil surface, T7 presented the best soil physical properties.

Keywords: Cropping systems, cover crops, clustering, soil structure 


\section{PROPRIEDADES FÍSICAS DO SOLO EM SISTEMA DE LONGA DURAÇÃO PARA A CEBOLA}

\section{RESUMO}

O objetivo foi avaliar atributos físicos do solo em diferentes sistemas de cultivo para cebola. O estudo foi conduzido em um Cambissolo Húmico Distrófico, em Ituporanga, SC, Brasil. Os seguintes tratamentos foram avaliados: T1: sucessão milho e cebola, T2: ervilhacamilho/centeio+nabo-cebola-milho/centeio+nabo-feijão; T3: centeio-cebola-milho/aveia-milho; T4: sucessão cebola-mucuna; T5: centeio-cebola-milheto/aveia-cebola-milheto; T6: sucessão centeio-cebola-mucuna; T7: sucessão cebola-milheto+mucuna+girassol. Os tratamentos de T1 até T7 foram conduzidos em sistema plantio direto, e T8 sucessão milho-cebola, foi conduzido em preparo convencional. O delineamento usado foi o de blocos completos casualizados, amostras de solo indeformadas foram colhidas nas camadas de 0-5, 5-10 e 10-20 cm e as variáveis analisadas foram: diâmetro médio geométrico de agregados, porosidade total, macroporosidade, microporosidade, densidade do solo e a relação macroporosidade/porosidade total. A análise de dados foi feita por meio da estatística univariada, análise de componentes principais e análise de agrupamento. Baseado nas características dos tratamentos, a análise de agrupamento definiu 3 grupos: grupo 1: T7; grupo 2: T1, T2, T3, T4, T5, T6; e grupo 3: T8. O preparo convencional apresentou indícios de degradação estrutural na camada superficial do solo. A melhor qualidade estrutural do solo foi observada no T7.

Palavras-chave: Sistemas de cultivo, plantas de cobertura, agrupamento, estrutura do solo

\section{INTRODUCTION}

Onion plays a significant economic role in Brazil corresponding to the main activity for nearly 60.5 thousand households. The Santa Catarina state is the leading onion grower in Brazil (KURTZ et al., 2019) and this activity is dealt by small and medium farmers, playing a significant role in the local socio-economic development, contributing to the generation of incomes, employment, and people establishment in rural areas (MENEZES JÚNIOR et al., 2014).

In Santa Catarina State, the conventional tillage system (CTS) is the dominant system used to grow onion (MENEZES JÚNIOR et al., 2014). Therefore, soils under this management are intensively degraded by the use of chisel and rotary tiller (EPAGRI, 2013; LOSS et al., 2015) 
which causes water, nutrients and soil losses by erosion (PANACHUKI et al., 2011) and can negatively affect soil physical properties (ARCOVERDE et al., 2019).

Another cropping system that can be used to grow onion is the no-tillage system (NTS). NTS has long been regarded as one of the most crucial cropping systems to enable sustainable cropping intensification to meet future agricultural demands (DERPSCH et al., 2014). In the NTS, soil disturbance is restricted to the planting rows, and cover crops are used to produce plant biomass, which is rolled down and left on the soil surface during the flowering period with the use of a knife-roller (SANTOS et al., 2017).

Crop residues and biomass accumulated by the cover crops are essential for the maintenance or recovery of soil physical and chemical properties in NTS (MENDONÇA et al., 2013). The decomposition of the cover crops straw increases biological activity (BABUJIA et al., 2010), nutrients, and soil organic matter (SOM) accumulation in the soil surface layer (LIMA FILHO et al., 2014). This cropping system also increases and promotes nutrients cycling, soil physical protection on the surface, soil aggregates formation (LOSS et al., 2015, 2017), and, therefore, promotes plant health (NICHOLLS et al., 2019).

The NTS includes crop rotation systems (CRS), which allow the inclusion of species with different root systems and crop residues with different $\mathrm{C} / \mathrm{N}$ ratios. $\mathrm{CRS}$ contribute to the alterations of decomposition rates and nutrients cycling. The crop residues at the soil surface benefit other crops in succession, improving the soil physical, chemical and biological properties (COSTA et al., 2015). Because of the soil conservation importance for onion growers some experiments are being conducted using different cropping systems. The use of cover crop residues increased water use and onion yields cultivated in NTS in comparison with CTS in Brazilian cerrado condition (MAROUELLI et al., 2010). In an agro-ecological NTS in Ituporanga's region the addition of cover crop residues in no-tillage contributed to the growth and onion yields over the years (SOUZA et al., 2013). This conservation system improves soil aggregation and organic carbon concentrations associated with use of cover crops for onion production (GIUMBELLI et al., 2020).

Therefore, understanding the changes which occur on the soil physical properties under NTS associated with crops rotation systems and the formation of cover crops are essential for the soil physical quality improvement in onion growing fields such as in Santa Catarina ones. This study aimed to evaluate soil physical properties in an experiment on onion cultivated under different cropping systems. 


\section{MATERIAL AND METHODS}

The experiment was established in 2007 in Ituporanga (27 $24^{\prime} 52^{\prime \prime} \mathrm{S}$ e 49 $36^{\prime} 9^{\prime \prime} \mathrm{W}, 475 \mathrm{~m}$ altitude), Santa Catarina State, Brazil, on a Humic Dystrudept (SOIL SURVEY STAFF, 2014). This area had been previously cultivated under no-tillage system (NTS) since 1995, when the soil was limed to $6 \mathrm{pH}$. The climate is a humid mesothermal with hot summers, Cfa, according to the Köppen classification (EMBRAPA, 2004). It has an average annual temperature of $17.6^{\circ} \mathrm{C}$ and an average annual precipitation of $1400 \mathrm{~mm}$ (COMIN et al., 2018). The soil particle size distribution is characterized by 430,300 and $270 \mathrm{~g} / \mathrm{kg}$ respectively of sand, clay and silt and $31 \mathrm{~g} / \mathrm{kg}$ of total organic carbon. The experiment was conducted in a randomized complete block design, with 5 replications and 8 treatments. The treatments were comprised by different cropping systems (Table $1)$.

All the treatments were cultivated under the no-tillage system (NTS) from 2007 to 2011. Since then, T8 has been managed under CTS (chisel and rotary tiller) to evaluate soil degradation after a previous conservation management. Each plot had an area of $8.7 \mathrm{~m}^{2}$, with seven planting rows of onion variety Epagri 352 with a planting distance of 0.4 x $0.1 \mathrm{~m}$. The selection of the cover species was based on traditional use, adaptation, seed availability, easiness to grow, and suitable mass production.

For soil physical analyses, undisturbed soil samples were collected in 2014 at the 0-5, 5-10 and 10-15 cm layers, using volumetric rings (internal diameter of $6 \mathrm{~cm}$, and height of $5 \mathrm{~cm}$ ). The following soil physical properties were evaluated: geometric mean diameter of aggregates (GMD), total porosity (TP), macroporosity (Macro), microporosity (Micro) and soil bulk density (BD). The GMD was determined according to Kemper and Chepil (1965). The soil samples were weighed and oven-dried at $105{ }^{\circ} \mathrm{C}$ for $48 \mathrm{~h}$ to quantify the soil bulk density (BD), soil particles density (SPD) was determined according to the volumetric balloon method (EMBRAPA, 2011). For the soil microporosity determination, the undisturbed soil samples were subject to water saturation and maintained on a suction table at a $60 \mathrm{~cm}$ suction, being the microporosity calculated by:Micro $=$ $\frac{S W_{60} \mathrm{~cm}^{-S D W}}{V}$, where SDW is the soil dry weight at $105{ }^{\circ} \mathrm{C}, \mathrm{V}$ is the volumetric ring volume $\left(\mathrm{cm}^{3}\right)$ and $S W_{60 \mathrm{~cm}}$ is the soil weight at $60 \mathrm{~cm}$ suction. Then the soil total porosity (TP) was obtained by the relationship between $\mathrm{BD}$ and $\operatorname{SPD}\left(T P=1-\frac{B D}{S P D}\right)$, and the macroporosity (Macro) by 
Macro $=$ TP - Microporosity (EMBRAPA, 2011). Using the treatments means, we calculated the porosities ratio (PR) by $P R=$ Macro $/ P T$.

Table 1. Treatments description in a long-term conservation system for onion, in Ituporanga, Santa Catarina State, Brazil (November, 2014).

\begin{tabular}{|c|c|c|c|}
\hline Treatments & Cropping system & Description & Crops family \\
\hline $\mathrm{T} 1$ & $\begin{array}{l}\text { Crops succession, } \\
\text { under NTS }\end{array}$ & $\begin{array}{l}\text { Maize (Zea mays L.) - onion (Allium } \\
\text { cepa } \mathrm{L} \text {.) }\end{array}$ & Poaceae and Liliaceae \\
\hline $\mathrm{T} 2$ & $\begin{array}{l}\text { Crops rotation, } \\
\text { under NTS }\end{array}$ & $\begin{array}{l}\text { Common vetch (Vicia sativa } \mathrm{L} .) \text { - } \\
\text { maize/rye (Secale cereale } \mathrm{L} .)+ \\
\text { fodder radish (Raphanus sativus } \mathrm{L} .) \text { - } \\
\text { onion-maize/rye+fodder radish- } \\
\text { common bean (Phaseolus vulgaris L.) }\end{array}$ & $\begin{array}{l}\text { Fabaceae, Poaceae } \\
\text { Brassicaceae and } \\
\text { Liliaceae }\end{array}$ \\
\hline $\mathrm{T} 3$ & $\begin{array}{l}\text { Crops rotation, } \\
\text { under NTS }\end{array}$ & $\begin{array}{l}\text { Rye-onion-maize/black oat (Avena } \\
\text { strigosa Schreb.) -maize }\end{array}$ & Poaceae and Liliaceae \\
\hline $\mathrm{T} 4$ & $\begin{array}{l}\text { Crops succession, } \\
\text { under NTS }\end{array}$ & $\begin{array}{l}\text { Onion-velvet bean (Stizolobium } \\
\text { aterrimum Piper and Tracy) }\end{array}$ & Liliaceae and Fabaceae \\
\hline T5 & $\begin{array}{l}\text { Crops rotation, } \\
\text { under NTS }\end{array}$ & $\begin{array}{l}\text { Rye-onion- pearl millet (Pennisetum } \\
\text { americanum L.)/black oat-onion-pearl } \\
\text { millet }\end{array}$ & Poaceae and Liliaceae \\
\hline $\mathrm{T} 6$ & $\begin{array}{l}\text { Crops succession, } \\
\text { under NTS }\end{array}$ & Rye-onion-velvet bean & $\begin{array}{l}\text { Poaceae, Liliaceae and } \\
\text { Fabaceae }\end{array}$ \\
\hline $\mathrm{T} 7$ & $\begin{array}{l}\text { Crops succession, } \\
\text { under NTS }\end{array}$ & $\begin{array}{l}\text { Onion-velvet bean+pearl } \\
\text { millet+sunflower (Helianthus annuus } \\
\text { L.) }\end{array}$ & $\begin{array}{l}\text { Liliaceae, Fabaceae, } \\
\text { Poaceae and Asteraceae }\end{array}$ \\
\hline T8 & $\begin{array}{l}\text { Crops succession, } \\
\text { under CTS }\end{array}$ & Maize-onion & Poaceae and Liliaceae \\
\hline
\end{tabular}

NTS stands for no tillage system and CTS conventional tillage system

The results in each layer were submitted to the Bartlett test of homogeneity of variances and Shapiro-Wilk normality test. Afterward, analysis of variance was performed. In cases of significant differences, treatment means comparison was performed using the Duncan test at 5\% significance level. In order to group the treatments based on their similarities, we performed the Kmeans clustering approach, using the $\mathrm{R}$ packages ggpubr and factoextra, according to our classification purpose, we predefined three groups. Principal components analysis was conducted 
to reduce the dimensionality of the data and to describe the variation observed on the data. This analysis was based on the correlation matrix. All the data analysis was performed on the $\mathrm{R}$ programming language. Useful details on cluster analysis and principal components analysis are available on Everitt and Hothorn (2011) and Härdle and Simar (2014).

\section{RESULTS AND DISCUSSION}

The geometric mean diameter of aggregates (GMD) at the $0-5 \mathrm{~cm}$ layer (Table 2), the cropping systems differed ( $\mathrm{p}<0.05)$, T8 had the lowest GMD and was similar to T1, in the same experiment, Giumbelli et al. (2020) found similar results, they attributed this result to the absence of cover crops in Summer and Winter, what reduces roots activity when compared to all the other treatments using cover crops. Besides, the lowest GMD observed in T8 also influenced by soil tillage which deteriorates the soil aggregates stability at the soil surface. Silva et al. (2016) studying physical properties of a Hapludox after three decades under different soil cropping systems found that CTS decreased aggregate stability to the depth of $10 \mathrm{~cm}$ when compared to the NTS.

According to Vezzani and Mielniczuk (2011), in the NTS the soil is not turned over, there is a maintenance of crop residues on the soil surface, and thus, higher contribution of organic matter throughout the years, thus the NTS contributes to recovery of soil structure in the long term. Loss et al. (2017) studying soil physical attributes of onion cultivation under NTS and CTS verified lower GMD in the treatment under CTS. Similar results were also observed by Loss et al. (2015), in a similar study by Comin et al. (2018) the use of NTS for onion generated higher soil aggregates stability than the CTS, however, in the present work there were no significant differences between T1 (NTS) and T8 (CTS). In this study, the GMD value presented by T2 in the 0-5 cm layer may be explained by the presence of rye+ fodder radish, fodder radish root system is pivoting and aggressive, thus when the roots grow, they press the soil particles around them, favouring the formation of more resistant and larger soil aggregates (GUEDES FILHO et al., 2013). Rorick and Kladivko (2017) studying rye cover crop effects on soil carbon and physical properties in Indiana (USA), discovered that rye after four years increased in 55\% the GMD when compared to the no cover control in the 0 to $10 \mathrm{~cm}$ soil layer. Rye has vigorous rooting (LIESCH et al., 2011), fibrous root system (VILLAMIL et al., 2006) must be considered to justify the GMD observed in the treatments which have rye in their composition (T2, T3, T5 and T6). The higher GMD values observed in T3, T4, T5, T6 than the CTS may be also explained by the effect of cover crops over 
the soil structure and the absence of soil tillage. Significant differences were not observed at the 510 and $10-15 \mathrm{~cm}$ layers.

Table 2. Geometric mean diameter of soil aggregates (GMD), soil bulk density (BD), microporosity (Micro), macroporosity (Macro), total porosity (TP) and porosities ratio (PR) under different cropping systems for onion, in Ituporanga, Santa Catarina State, Brazil (November, 2014).

\begin{tabular}{|c|c|c|c|c|c|c|}
\hline Treatments & $\begin{array}{l}\text { GMD } \\
\mathrm{mm}\end{array}$ & $\begin{array}{l}\mathrm{BD} \\
\mathrm{Mg} / \mathrm{m}^{3}\end{array}$ & $\begin{array}{l}\text { Micro } \\
\mathrm{m}^{3} / \mathrm{m}^{3}\end{array}$ & $\begin{array}{l}\text { Macro } \\
\mathrm{m}^{3} / \mathrm{m}^{3}\end{array}$ & $\begin{array}{c}\mathrm{TP} \\
\mathrm{m}^{3} / \mathrm{m}^{3}\end{array}$ & $\overline{P R}$ \\
\hline
\end{tabular}

$0-5 \mathrm{~cm}$ layer

$\begin{array}{lllllll}\text { T1 } & 4.16 \mathrm{ab} & 1.34 \mathrm{a} & 0.38^{\mathrm{WD}} & 0.04 \mathrm{~b} & 0.43 \mathrm{~b} & 0.11^{\mathrm{WD}} \\ \text { T2 } & 5.24 \mathrm{a} & 1.28 \mathrm{ab} & 0.39 & 0.04 \mathrm{~b} & 0.44 \mathrm{~b} & 0.11 \\ \mathrm{~T} 3 & 4.93 \mathrm{a} & 1.21 \mathrm{abc} & 0.38 & 0.10 \mathrm{ab} & 0.49 \mathrm{ab} & 0.22 \\ \text { T4 } & 4.68 \mathrm{a} & 1.23 \mathrm{abc} & 0.38 & 0.08 \mathrm{ab} & 0.46 \mathrm{ab} & 0.18 \\ \text { T5 } & 4.92 \mathrm{a} & 1.17 \mathrm{bc} & 0.39 & 0.08 \mathrm{ab} & 0.47 \mathrm{ab} & 0.17 \\ \text { T6 } & 4.66 \mathrm{a} & 1.25 \mathrm{ab} & 0.38 & 0.08 \mathrm{ab} & 0.47 \mathrm{ab} & 0.18 \\ \text { T7 } & 4.78 \mathrm{a} & 1.11 \mathrm{c} & 0.36 & 0.16 \mathrm{a} & 0.53 \mathrm{a} & 0.31 \\ \text { T8 } & 3.15 \mathrm{~b} & 1.29 \mathrm{ab} & 0.36 & 0.13 \mathrm{a} & 0.50 \mathrm{ab} & 0.28\end{array}$

$5-10 \mathrm{~cm}$ layer

$\begin{array}{lllllll}\text { T1 } & 5.07^{\mathrm{WD}} & 1.38^{\mathrm{WD}} & 0.37^{\mathrm{WD}} & 0.05^{\mathrm{WD}} & 0.43 \mathrm{WD} & 0.13^{\mathrm{WD}} \\ \mathrm{T} 2 & 4.77 & 1.39 & 0.37 & 0.05 & 0.42 & 0.12 \\ \mathrm{~T} 3 & 5.23 & 1.38 & 0.37 & 0.05 & 0.42 & 0.12 \\ \mathrm{~T} 4 & 4.56 & 1.40 & 0.37 & 0.03 & 0.41 & 0.10 \\ \mathrm{~T} 5 & 5.08 & 1.41 & 0.38 & 0.02 & 0.40 & 0.05 \\ \mathrm{~T} 6 & 5.08 & 1.37 & 0.37 & 0.05 & 0.42 & 0.13 \\ \mathrm{~T} 7 & 4.67 & 1.39 & 0.36 & 0.06 & 0.42 & 0.14 \\ \mathrm{~T} 8 & 4.17 & 1.36 & 0.37 & 0.06 & 0.43 & 0.14\end{array}$

$10-20 \mathrm{~cm}$ layer

\begin{tabular}{lllllll} 
T1 & $4.38^{\mathrm{WD}}$ & $1.36^{\mathrm{WD}}$ & $0.35^{\mathrm{WD}}$ & $0.06^{\mathrm{WD}}$ & $0.42^{\mathrm{WD}}$ & $0.16^{\mathrm{WD}}$ \\
$\mathrm{T} 2$ & 3.73 & 1.41 & 0.37 & 0.06 & 0.44 & 0.15 \\
$\mathrm{~T} 3$ & 4.74 & 1.38 & 0.37 & 0.05 & 0.42 & 0.12 \\
$\mathrm{~T} 4$ & 2.76 & 1.44 & 0.39 & 0.02 & 0.42 & 0.06 \\
$\mathrm{~T} 5$ & 4.49 & 1.4 & 0.38 & 0.02 & 0.40 & 0.06 \\
$\mathrm{~T} 6$ & 3.42 & 1.43 & 0.37 & 0.05 & 0.42 & 0.12 \\
T7 & 4.24 & 1.39 & 0.37 & 0.07 & 0.45 & 0.17 \\
T8 & 3.84 & 1.37 & 0.38 & 0.06 & 0.44 & 0.14 \\
\hline
\end{tabular}

T1: maize-onion succession, T2: common vetch-maize/rye+fodder radish-onion-maize/rye+fodder radish-common bean, T3: rye-onion-maize/black oat-maize, T4: onion-velvet bean succession, T5: rye-onion-millet/black oat-onionmillet, T6: rye-onion-velvet bean succession, T7: onion-velvet bean+millet+sunflower succession, conventional tillage T8: maize-onion succession WD stands for without significant differences at 5\% 
For soil bulk density (BD), significant differences were only observed at the 0-5 cm layer, T1 presented the highest BD value, despite being similar to some other treatments (T2, T3, T4, T6 and T8). T1 BD value may be explained by the absence of cover crops and thus reduced roots diversity. The absence of soil tillage in $\mathrm{T} 1$ is also a factor to be considered to explain its BD value. T8 BD value was affected by soil tillage, as soil tillage reduces the BD mainly at the soil surface, but even so, T7 presented lower BD than T8, T7 presented the lowest BD (despite being similar to $\mathrm{T} 5)$, the BD in $\mathrm{T} 7$ may be explained by the soil conjoint exploration of three different crops families, Fabaceae (velvet bean), Poaceae +Asteraceae (pearl millet +sunflower), these groups of crops own different roots systems which after the roots mass decomposition contribute to the formation of an architecture of permanent pores, decreasing the BD and increasing PT and macroporosity (MENDONÇA et al., 2013).

These results differ from the ones obtained by Loss et al. (2017), where the CTS presented lower BD than the NTS at the 10- $15 \mathrm{~cm}$ layer. These authors attributed the result to soil tillage which overturns the soil. Costa et al. (2003) studying the effects of 21 years of cropping systems on the soil physical properties in an Oxisol observed that the CTS presented higher BD values than the NTS at the 10-20 cm layer. These authors attributed this result to the pressure from agricultural machinery which is transmitted to the soil deeper layers. The same authors reported that the soil type, the soil moisture condition in which the operations are performed along the crops cycle, and the length of time that soil management practices are adopted are important variables that must considered on evaluating soil structure.

For soil microporosity (Micro), the cropping systems were similar in all the layers ( $p>0.05)$. In this case, the reduced variation observed in the microporosity possibly indicates that the cropping systems had less influence on this soil property. Similar results were also observed by Bertol et al. (2001, 2004) in an Inceptisol and by Loss et al. (2017) in a Humic Cambisol. Silva et al. (2016) reported higher microporosity in the NTS than in the CTS especially at the 0-10 cm layer.

For the soil macroporosity (Macro), significant differences were only observed at the 0-5 cm layer. T7 and T8 had the highest values. The higher macroporosity observed in T7 is related to the lowest BD observed in this layer. For T8, macroporosity was influenced by soil tillage, because soil tillage at the surface layer increases soil macroporosity and total porosity. The lowest macroporosities observed in $\mathrm{T} 1$ and $\mathrm{T} 2$ are related to the higher BD values observed in both 
treatments. Silva et al. (2016) reported higher macroporosity down to a depth of $10 \mathrm{~cm}$ in the CTS than in the NTS. These authors attributed this result to the soil mobilization in Winter and SpringSummer in the CTS.

For total porosity (TP) significant differences were only observed at the $0-5 \mathrm{~cm}$ layer, where T7 presented the highest value, being significantly higher than T1 and T2. TP presented the same trend observed by soil macroporosity. Loss et al. (2017) observed lower TP in the CTS than in the NTS at the 0-5 cm layer and in the deeper layers differences were not observed as in our study. For TP, we can also observe the advantages of NTS, despite the absence of soil tillage, the permanent soil cover stimulates soil biota activity which is responsible for the soil pores formation and consequently the increase of soil TP (T3, T4, T5, T6 and T7). These results differ from the ones obtained by Silva et al. (2016), where TP was similar between the cropping systems, except for the 60-100 $\mathrm{cm}$ soil layer. According to these authors, these differences can be related to the distinct soil moisture conditions at the time of soil tillage, to the different crop treatments applied, and to the diverse contributions of biomass addition from different crops.

For the porosities ratio (PR) which is a soil compaction indicator, treatments were similar in all the layers ( $p>5 \%)$, PR followed the same trend as TP and macroporosity, as all these three variables are positively correlated (Table 3). It is also important to consider that T8 (CTS) was established in 2011 and the other treatments in 2007, which may be insufficient time to observe changes in this property.

For principal components analysis (Table 3), the principal component 1 (PC 1) and PC 2 explained nearly $96 \%$ of the total variability observed on the data. PC 1 explained $72.8 \%$ of the total variability and is comprised mainly by TP, Macro, Micro, BD, PR. PC 2 explained $24 \%$ of the total variability and is comprised mainly by GMD.

The PCA revealed strong positive correlations among Macro, TP and PR (group 1 of variables), positive correlations between $\mathrm{BD}$ and Micro (group 2 of variables) and negative correlations between group 1 and group 2 of variables, GMD by itself forms a unique group (group $3)$.

For the treatments clustering, the K-means clustering approach revealed the presence of three different clusters, namely: cluster 1: T7, cluster 2: T1, T2, T3, T4, T5, T6 and cluster 3: T8. Figure 1 presents graphically these results. 
Table 3. Principal components analysis results under different cropping systems for onion, in Ituporanga, Santa Catarina State, Brazil (November, 2014).

\begin{tabular}{|c|c|c|c|c|c|c|}
\hline \multicolumn{7}{|c|}{ Importance of principal components } \\
\hline & PC 1 & PC 2 & PC 3 & PC 4 & PC 5 & PC 6 \\
\hline Stan dev & 2.09 & 1.2 & 0.34 & 0.26 & 0.02 & 0.00 \\
\hline Prop of var & 0.72 & 0.24 & 0.02 & 0.01 & 0.00 & 0.00 \\
\hline Cumul prop & 0.72 & 0.96 & 0.98 & 0.99 & 1 & 1 \\
\hline \multicolumn{7}{|c|}{ Correlation of the principal components with the response variables } \\
\hline & PC 1 & PC 2 & PC 3 & $\mathrm{PC} 4$ & PC 5 & PC 6 \\
\hline $\mathrm{TP}$ & -0.98 & 0.15 & 0.16 & -0.02 & -0.01 & -0.00 \\
\hline Macro & -0.99 & 0.02 & 0.07 & 0.03 & -0.01 & 0.00 \\
\hline Micro & 0.89 & 0.37 & 0.19 & -0.16 & 0.00 & 0.00 \\
\hline GMD & 0.36 & 0.92 & 0.03 & 0.16 & 0.00 & 0.00 \\
\hline $\mathrm{BD}$ & 0.72 & -0.66 & 0.19 & 0.14 & -0.00 & 0.00 \\
\hline PR & -0.99 & 0.02 & 0.1 & 0.01 & 0.02 & -0.00 \\
\hline
\end{tabular}

Loadings of the response variables in each principal component

\begin{tabular}{lcccccc}
\hline & PC 1 & PC 2 & PC 3 & PC 4 & PC 5 & PC 6 \\
\hline TP & -0.46 & 0.13 & 0.46 & -0.07 & -0.44 & -0.6 \\
Macro & -0.47 & 0.02 & 0.21 & 0.10 & -0.35 & 0.77 \\
Micro & 0.42 & 0.31 & 0.57 & -0.59 & 0.05 & 0.20 \\
GMD & 0.17 & 0.77 & 0.08 & 0.61 & 0.03 & 0.00 \\
BD & 0.34 & -0.55 & 0.57 & 0.51 & -0.01 & 0.00 \\
PR & -0.47 & 0.02 & 0.30 & 0.03 & 0.83 & -0.01
\end{tabular}

PC: Principal component, Stan dev: Standard deviation, Prop of var: Proportion of variance, Cumul prop: Cumulative proportion, BD: soil bulk density, TP: total porosity, Micro: microporosity, Macro: macroporosity and GMD: geometric mean diameter of soil aggregates 


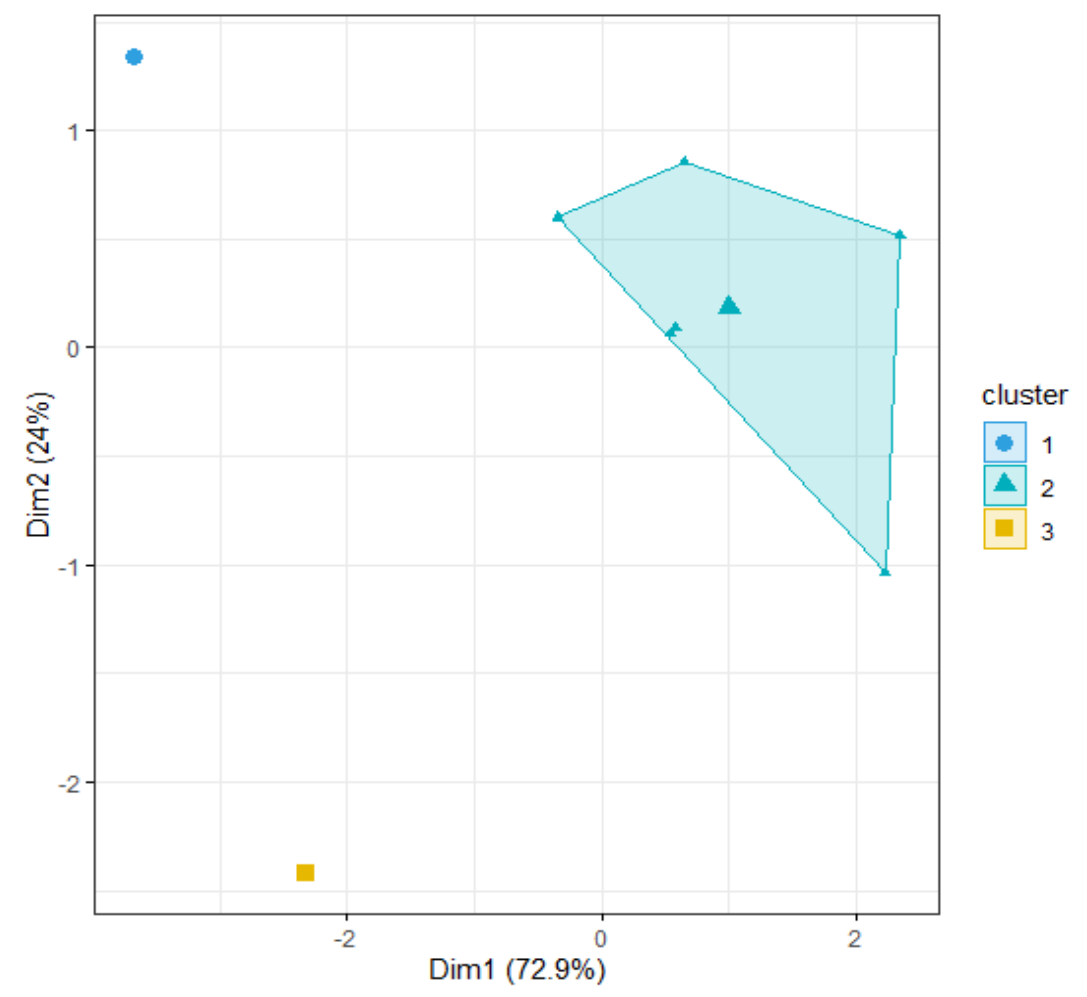

Cluster 1: T7; Cluster 2: T1, T2, T3, T4, T5, T6 and Cluster 3: T8

Dim1: Principal component 1, the same for Dim 2

Figure 1. Treatments clustering under different cropping systems for onion, in Ituporanga, Santa Catarina State, Brazil (November, 2014).

Interesting to note that T7 (onion-velvet bean+millet+sunflower) is separated from the other treatments, in general, when compared to all the other treatments, T7 presented better soil physical properties. Cluster 2 is comprised by all the other treatments conducted under NTS, some of these treatments, at the $0-5 \mathrm{~cm}$ layer, presented indication of structure deterioration (T1) evidenced by the reduced GMD (similar to T8). T8 is the unique treatment in cluster 3, at the $0-5 \mathrm{~cm}$ layer presented the lowest GMD but was better in some other soil physical properties when compared to other treatments in cluster 2, as seen previously in the univariate analysis (Table 2).

\section{CONCLUSIONS}

In general, significant differences were only observed at the $0-5 \mathrm{~cm}$ layer, meaning that more time may be needed to observe the behaviour of the deeper layers. 
The use of NTS associated to cover crops was useful to maintain the soil physical quality, despite some significant differences observed among some of them.

The conventional tillage system showed evidence of soil structure deteriorating mainly at the soil surface layer.

The conjoint use of cover crops from different families (Liliaceae, Fabaceae, Poaceae and Asteraceae) observed in T7 (onion-velvet bean+millet+sunflower) was the best cropping system in terms of soil structure quality.

\section{REFERENCES}

ARCOVERDE, S. N. S.; CORTEZ, J. W.; OLSZEVSKI, N.; SALVIANO, A. M.; GIONGO, V. 2019. Multivariate analysis of chemical and physical attributes of Quartzipsamments under different agricultural uses. Engenharia Agrícola, Jaboticabal, v. 39, n. 4, p. 457-465. DOI: http://dx.doi.org/10.1590/1809-4430-Eng.Agric.v39n4p457-465/2019

BABUJIA, L. C.; HUNGRIA, M.; FRANCHINI, J. C.; BROOKES, P. C. 2010. Microbial biomass and activity at various soil depths in a Brazilian oxisol after two decades of no-tillage and conventional tillage. Soil Biology and Biochemistry, Oxford, England, v. 42, n. 12, p. 21742181. DOI: https://doi.org/10.1016/j.soilbio.2010.08.013

BERTOL, I.; BEUTLER, J. F.; LEITE, D.; BATISTELA, O. 2001. Propriedades físicas de um Cambissolo Húmico afetadas pelo tipo de manejo do solo. Scientia Agricola, Piracicaba, v. 58, n. 3, p. 555-60. DOI: http://dx.doi.org/10.1590/S0103-90162001000300018

BERTOL, I.; AlBUQUERQUE, J. A.; LEITE, D.; AMARAL, A. J.; JUNIOR, W. A. Z. 2004. Propriedades físicas do solo sob preparo convencional e semeadura direta em rotação e sucessão de culturas, comparadas às do campo nativo. Revista Brasileira de Ciência do Solo, Viçosa, v. 28, p. 155-63. DOI: http://dx.doi.org/10.1590/S0100-06832004000100015

COMIN, J. J.; FERREIRA, L. B.; SANTOS, L. H.; KOUCHER, L. P.; MACHADO, JUNIOR, L. N.; E. S.; MAFRA, A. L; KURTZ, C.; SOUZA, M.; BRUNETTO, G.; LOSS, A. 2018. Carbon and nitrogen contents and aggregation index of soil cultivated with onion for seven years using crop successions and rotations. Soil and Tillage Research, Amsterdam, Netherlands, v. 184, p. 195-202. DOI: https://doi.org/10.1016/j.still.2018.08.002

COSTA, F. S.; ALBUQUERQUE, J. A.; BAYER, C.; FONTOURA, S.; WOBETO, C. 2003. Propriedades físicas de um Latossolo Bruno afetadas pelos sistemas plantio direto e preparo convencional. Revista Brasileira de Ciência do Solo, Viçosa, v. 27, p. 527-35. DOI: http://dx.doi.org/10.1590/S0100-06832003000300014

COSTA, N. R.; ANDREOTTI, M.; LOPES, K. S. M.; YOKOBATAKE, K. L.; FERREIRA, J. P; PARIZ, C. M.; BONINI, C. S. B.; LONGHINI, V. Z. 2015. Atributos do solo e acúmulo de carbono na integração lavoura-pecuária em sistema plantio direto. Revista Brasileira de Ciência do Solo, Viçosa, v. 39, p. 852-863. DOI: 10.1590/01000683rbcs20140269

DERPSCH, R.; FRANZLUEBBERS, A. J.; DUIKER, S. W.; REICOSKY, D. C.; KOELLER, K.; FRIEDRICH, T.; STURNY, W. G.; SÁ, J. C. M.; K. WESS. 2014. Why do we need to standardize no-tillage research? Soil and Tillage Research, Amsterdam, Netherlands, v. 137, p. 16-22. DOI: http://dx.doi.org/10.1016/j.still.2013.10.002 
EMBRAPA. Centro Nacional de Pesquisa de Solos. 2004. Solos do Estado de Santa Catarina. Embrapa Solos, Boletim de Pesquisa e Desenvolvimento, 46. Rio de Janeiro, Brasil

EMBRAPA. Centro Nacional de Pesquisa de Solos. 2011. Manual de métodos de análise de solo. 3. ed. rev. e atualizada. Rio de Janeiro, Brasil.

EPAGRI. 2013. Sistema de produção para cebola: Santa Catarina. Florianópolis: Epagri. 106p EVERITT, B.; HOTHORN, T. 2011. An Introduction to Applied multivariate Analysis with R. New York: Springer. DOI: 10.1007/978-1-4419-9650-3

GIUMBELLI, L. D.; LOSS, A.; VENTURA, B. S.; JÚNIOR, E. S.; ALMEIDA, J.; PICCOLO, M. C.; MAFRA, A. L.; KURTZ, C.; BRUNETTO, G.; COMIN, J. J. 2020. Aggregation index, carbon, nitrogen, and natural abundance of ${ }^{13} \mathrm{C}$ and ${ }^{15} \mathrm{~N}$ in soil aggregates and bulk soil cultivated with onion under crop successions and rotations. Soil Research, Australia, v. 58, p. 622-635. DOI: 10.1071/SR19346

GUEDES FILHO, O.; SILVA, A. P.; GIAROLA, N. F. B.; TORMENA, C. A. 2013. Structural properties of the soil seedbed submitted to mechanical and biological chiseling under notillage. Geoderma, Netherlands, v. 204-205, p. 94-101. DOI: 10.1016/j. geoderma.2013.04.017

HÄRDLE, W. K.; SIMAR, L. 2014. Applied Multivariate Statistical Analysis. New York, USA: Springer, $4^{\text {th }}$ Ed. DOI: 10.1007/978-3-662-45171-7

KEMPER, W. D.; CHEPIL, W. S. 1965. Size distribution of aggregation. In: BLACK, C. A. (ed.) Methods of soil analysis. USA, Madison: American Society of Agronomy, p. 499-510.

KURTZ, C.; SGROTT, E. Z.; COMIN, J. J.; HIGASHIKAWA, F. S.; SOUZA, M. 2019. Sistema de plantio direto de hortaliças: princípios de transição para sistemas de produção ecológicos e redesenho de propriedades familiares. In: FAYAD, J. A.; ARL, V.; COMIN, J. J.; MAFRA, A. L.; MARCHESI, D. R. (eds.) Sistema de plantio direto de hortaliças: métodos de transição para um novo modo de produção. São Paulo: Expressão Popular, 1 ed. 432p

LIESCH, A. M.; KRUEGER, E. S.; OCHSNER, T. E. 2011. Soil Structure and Physical Properties under Rye-Corn Silage Double-Cropping Systems. Science Society of America Journal, Madison, USA, v. 75, p. 1307-1314. DOI: 10.2136/sssaj2010.0292

LIMA FILHO, O. F.; AMBROSANO, E. J.; ROSSI, F.; CARLOS, J. A. D. (eds.) 2014. Adubação verde e plantas de cobertura no Brasil: fundamentos e prática. Brasília: Embrapa, v. 1. $507 \mathrm{p}$

LOSS, A; BASSO, A.; OLIVEIRA, B. S.; KOUCHER, L. P; OLIVEIRA, R. A.; KURTZ, C.; LOVATO, P. E.; CURMI, P.; BRUNETTO, G.; COMIN, J. J. 2015. Carbono orgânico total e agregação do solo em sistema de plantio direto agroecológico e convencional de cebola. Revista Brasileira de Ciência do Solo, Viçosa, v. 39, p. 1212-1224. DOI: http://dx.doi.org/10.1590/01000683rbcs20140718

LOSS, A.; JUNIOR, E. S.; SCHMITZ, D.; VEIGA, M.; KURTZ, C.; COMIN, J. J. 2017. Atributos físicos do solo sob sistemas de plantio direto e preparo convencional em cultivo de cebola. Revista Colombiana de Ciencias Horticolas, Tunja, Boyacá, Colombia, v. 11, n. 1, p. 105113. DOI: http://dx.doi.org/10.17584/rcch.2017v11i1.6144

MAROUELli, W. A.; ABDALlA, R. P.; MADEIRA, N. R; SILVA, H. R.; OLIVEIRA, A. S. 2010. Water use and onion crop production in no-tillage and conventional cropping systems. Horticultura Brasileira, Recife, Pernambuco. v. 28, p. 19-22. DOI: http://dx.doi.org/10.1590/S0102-05362010000100004

MENDONÇA, V. Z.; MELLO, L. M. M.; ANDREOTTI, M.; PEREIRA, F. C. B. L.; LIMA, R. C.; FILHO, W. V. V.; YANO, E. H. 2013. Avaliação dos atributos físicos do solo em consórcio 
de forrageiras e milho em sucessão com soja em região de Cerrados. Revista Brasileira de Ciência do Solo, Viçosa, v. 37, p. 251-259. DOI: http://dx.doi.org/10.1590/S010006832013000100026

MENEZES JÚNIOR, F. O. G.; GONÇALVES, P. A. S.; VIEIRA NETO, J. 2014. Produtividade da cebola em cultivo mínimo no sistema convencional e orgânico com biofertilizantes. Horticultura Brasileira, Recife, Pernambuco, v. 32, p. 475-81. DOI: http://dx.doi.org/10.1590/S0102-053620140000400017

NICHOLLS, C. I.; ALTIERI, M. A.; VASQUEZ, L.; VENTURA, B. S.; FERREIRA, G. W.; COMIN, J. J. 2019. Sistema de plantio direto de hortaliças: princípios de transição para sistemas de produção ecológicos e redesenho de propriedades familiares. In: FAYAD, J. A.; ARL, V.; COMIN, J. J.; MAFRA, A. L.; MARCHESI, D. R. (eds.) Sistema de plantio direto de hortaliças: métodos de transição para um novo modo de produção. São Paulo: Expressão Popular, 1 ed. 432p.

PANACHUKI, E.; BERTOL, I.; SOBRINHO, T. A.; OLIVEIRA, P. T. S.; RODRIGUES, D. B. B. 2011. Perdas de solo e de água e infiltração de água em Latossolo Vermelho sob sistemas de manejo. Revista Brasileira de Ciência do Solo, Viçosa, v. 35, p. 1777-85. DOI: http://dx.doi.org/10.1590/S0100-06832011000500032

RORICK, J. D.; KLADIVKO, E. J. 2017. Cereal rye cover crop effects on soil carbon and physical properties in southeastern Indiana. Journal of Soil and Water Conservation, Indiana, USA, v. 72 , n. 3, p. 260-265. DOI: 10.2489/jswc.72.3.260

SANTOS, L. H.; CANTON, L.; VENTURA, B. S.; FERREIRA, G. W.; KURTZ, C.; BRUNETTO, G.; COMIN, J. J.; LOVATO, P. E.; LOSS, A. 2017. Chemical properties in macroaggregates of a Humic Dystrudept cultivated with onion under no-till and conventional tillage systems. Revista Brasileira de Ciência do Solo, Viçosa, v. 41, p. 1-13. DOI: https://doi.org/10.1590/18069657rbcs20160419

SILVA, F. R.; AlBUQUeRQUE, J. A.; COSTA, A.; FONTOURA, S. M. V.; BAYER, C; WARMLING, M. I. 2016. Physical properties of a Hapludox after three decades under different soil management systems. Revista Brasileira de Ciência do Solo, Viçosa, v. 40, p. 1-14. DOI: $10.1590 / 18069657 \mathrm{rbcs} 20140331$

SOIL SURVEY STAFF. 2014. Keys to Soil Taxonomy. Washington, DC, USA: Department of Agriculture (USDA), Natural Resources Conservation Service (NRCS), 12th ed. 372p

SOUZA, M.; COMIN, J. J.; LEGUIZAMÓN, E. S.; KURTZ, C.; BRUNETTO, G.; JÚNIOR, V. M.; VENTURA, B.; CAMARGO, A. P. 2013. Matéria seca de plantas de cobertura, produção de cebola e atributos químicos do solo em sistema plantio direto agroecológico. Ciência Rural, Santa Maria, v. 43, n. 1, p. 21-27. DOI: https://doi.org/10.1590/S0103-84782012005000150

VEZZANI, F. M.; MIELNICZUK, J. 2011. Agregação e estoque de carbono em Argissolo submetido a diferentes práticas de manejo agrícola. Revista Brasileira de Ciência do Solo, Viçosa, MG, v. 35, p. 213-223. DOI: 10.1590/S0100-06832011000100020

VILLAMIL, M. B.; BOLLERO, G. A.; DARMODY, R.G.; SIMMONS, F.W.; BULLOCK, D. G. 2006. No-till corn/ soybean systems including winter cover crops: Effects on soil properties. Soil Science Society of America Journal, Madison, USA, v. 70, p. 1936-1944. DOI: https://doi.org/10.2136/sssaj2005.0350 